\title{
Assessment Of Factors Affecting Road Pavement Design And Remedial Actions
}

\author{
Eshetu Mathewos Juta \\ ${ }^{1}$ Assistant Professor, Civil Engineering Department, Wolaita Sodo University, Wolaita Sodo, Ethiopia \\ Email Id: eshetum90@gmail.com
}

\begin{abstract}
Many factors such as number of vehicles, speed, climatic conditions and other factors affect are to be considered for the design of pavement. In this article we will discuss about the factors influencing pavement design. Pavements are engineered structures which are used as roads, runways, parking areas, etc. Ground or surface transportation is the most widely used transportation in the world. So, construction of pavements should be done as it is strong and durable for their design life. There are so many factors which influencing the pavement design. The factors may be of loading, environment, materials used etc. Which are as follows Wheel load, Axle configuration, Contact pressure, Vehicle speed, Repetition of loads, Subgrade type, Temperature and Precipitation. This paper aims to present a review on the performance, problems and possible remedial measures practices for roads constructed on these problematic soils in the country. Finally, emphasis should be given to the importance in construction in this kind of soil of strictly applying engineered design of geometric, drainage, pavement thickness, material selection and proportioning. Thus, those concerned bodies shall decide to accept and control the risk associated with construction on this soil or not, or to decide that more detail study is required to allow for extra design and construction preemptive measures once the potential problem has been identified and the end user convinced of the cost-savings in adopting a pro-active approach.
\end{abstract}

\section{INTRODUCTION}

The economic growth of a community is depending up on the highway developments or road availability to enhance mobility. Since the rapid development of urbanization and industrialization, the increasing use of motor Vehicles, bicycles, on urban road systems, as well as other relevant problems, have made the road Systems more difficult. In the Third World and less developed countries there are sections of the road, subjected to heavy Traffic flow ,aligned by poor building stock, containing mixed land-use, void of landscaping, with discordant power poles and street structures. (JO Oluwoye, 1997). Road users include drivers, passengers, pedestrians etc. who use the streets and highways. Together, they form the most complex element of the traffic system. The human element which differentiates transportation engineering from al (., 1961) (JO Oluwoye, 1997)l other engineering fields. It is said to be the most complex factor as the human performances varies from individual to individual. Thus, the transportation engineer should deal with a variety of road user characteristics. For example, a traffic signal timed to permit an average pedestrian to cross the street safely may cause a severe hazard to an elderly person.

\subsection{Statement of the problem}

Different problems or factors that affect roads design, such as environmental factor, human factors, vehicles and road way and finances. Generally different problems or factors that on road design for e.g. economical problems.it means to design a good road requires expensive costs for more suitable and sustainable for peoples. And also environmental factors more affects the road design because the design must be considers such as geography, forests; wildlife's, airs and water bodies. We see the human factors such as the people characters how to use of the road and speeds of the drivers. Speeding is one of the major problems confronting traffic safety engineers. (addminstration, 2009). Road project is a complex and vast which needs a carefully prepared road design. Due to many design factors the serviceability of roads fail so that most of roads in Ethiopia have short life span and becomes uncomfortable for traffics by creating bores and cracks so this research is conducted to overcome such problems related with road design factors. There are a number of factors affecting road design in depth understanding these factors which affect road design is a very crucial task at the design phase. In ability to consider these factors and their effect on road projects at the design phase will have different consequence like difficulty in performance of the project, time over run, cost overrun dispute even though termination of the project. Therefore, it is very important to identify on the factors affecting road design, consequently we are initiated to conduct our study on this title. 


\subsection{Objective/aim of the study}

In this research our main objective is to identify the major factors affecting road design we try to identify the major factors affecting road design, investigates. Which of these factors are the most influential one in road design and finally we try to find out the ways of minimizing their influence in road design., To identify the major factors affecting the road design. To investigate which factors have the most impact on road design, To examine how these factors affect road design and To find out the ways of minimizing the influence these factors on road design. What are the Factors that influence road design? Which factors have the most impact on road design? What are the possible ways of minimizing the influence of factors affecting road design?

\subsection{Significance of the study}

To contribute our effort on the issue under discussion. To draw conclusion and give recommendations based on research finding and to indicate further study. The study will also lay the foundations for further research on the subject matter titles related to this.

\section{LITERARURE REVIEW}

A road is an area that is open to or used by the public and is developed for, or it has as One of its main uses, the driving or riding of motor vehicles. Some definitions, particularly of areas or lengths of road that are established by traffic signs or road markings, are complex or need diagrams to be fully understood. They are placed with the basic rule that deals with the area or length of road, so that the rule and the definition (with any accompanying diagrams) can be seen and understood together (South Australia Australian Road Rules under the Road Traffic Act 1961). There is often a difference between the common understanding of what a road is, and the wider, legal definition that is used in enforcing the laws that control the use of motor vehicles and the behavior of drivers, cyclists, pedestrians and other road users.

\subsection{Common law definition of 'road'}

Exercised on a road was that of traveling from one place to another. Obstructing or interfering with someone Elise's rights to the use of the road was a criminal offence.There is another statutory approach to the definition of road that is used in New Zealand. It is found used in Acts that provide for the funding, construction and traffic management powers of central and local government agencies. This definition refers to areas clearly taken for use as roads by the general public. In common law terms, these are public roads or highways, which the public are permitted to access and use ( (Government, 1974) (external link).. Common law Terms Street and wayare terms used interchangeably with road. Another is highway - this is simply a road or street dedicated for public use, normally between two localities or towns, and is often referred to as a public highway or public road.

\subsection{Road functions}

Roads are built with one major function in mind: to enable people and goods to travel from one place to another. Differentiating within this traffic function as a whole, individual roads may serve parts of the total! travel process in particular: some roads cope with long distance traffic only, others play a role as distributors in areas with scattered destinations, and some roads just grant direct access to properties alongside or allow vehicles to be parked on them at the end of a trip. In the following sections a distinction will be made between three aspects of the traffic function:

$\checkmark$ Flow function: rapid processing of through traffic; Distributor function: making districts and regions accessible;Access function: allowing properties to be reached.

\subsection{Assumptions used in road design}

Most road design standards give definite instructions for the layout of the various elements of a road: dimensions or even complete drawings are provided. Information on the background of these instructions is only rarely added. There is no indication of the relative importance that was given to road safety, in comparison to traffic flow, easy reach of destinations, environment, costs, etc. Often, it is not even clear to what extent a certain standard was based upon factual figure sand relations and to what extent upon assumptions. One cannot get around factual figures, but assumptions can be altered or at least deviated from occasionally. With regard to this, it should be known how firm a certain assumption is; and whether it is to be considered as an underlying basic assumption or as an occasional assumption. 


\subsection{Elements of design}

Sight distance is the length of the roadway ahead that is visible to the driver. The available sight distance on a roadway should be sufficiently long to enable a vehicle traveling at or near the design speed to stop before reaching a stationary object in its path. Although greater lengths of visible roadway are desirable, the sight distance at every point along a roadway should be at least that needed for a below-average driver or vehicle to stop. The distance traversed by the vehicle from the instant the driver sights an object necessitating a stop to the instant the brakes are applied; and the distance needed to stop the vehicle from the instant brake application begins. These are referred to as brake reaction distance and breaking distance respectively (Johansson, G., and K. Rumar. The study of reaction times by was based on data from 321 drivers who expected to apply their brakes.

\subsection{Design values}

Stopping sight distances exceeding those shown in Exhibit 3-1 should be used as the basis for design wherever practical. Use of longer stopping sight distances increases the margin of safety for all drivers and, in particular, for those who operate at or near the design speed. To ensure that new pavements will have initially, and will retain, friction coefficients comparable to the deceleration rates used to develop Exhibit 3-1, pavement designs should meet the criteria (Washington, D .C.: 1975). Studies documented in the literature (Washington,D.C.:1988or most current edition). show that most drivers decelerate at a rate greater than $4.5 \mathrm{~m} / \mathrm{s}^{2}$ when confronted with the need to stop for an unexpected object in Tread way. Approximately 90 percent of all drivers decelerate at rates greater than $3.4 \mathrm{~m} / \mathrm{s}$. Such decelerations are within the driver's capability to stay within his or her lane and maintain steering control during the braking maneuver on wet surfaces. Therefore, $3.4 \mathrm{~m} / \mathrm{s}^{2}$ (a comfortable deceleration for most drivers) is recommended as the deceleration.

\section{LOCAL RURAL ROADS AND STREETS}

\subsection{General Design Considerations}

Width of Traveled Way, Shoulder, and Roadway . Graded shoulder width is measured from the edge of the traveled way to the point of intersection of shoulder slope and fore slope. The minimum roadway width is the sum of the traveled way and graded shoulder widths given. Where roadside barriers are proposed, it is desirable to provide a minimum offset of $1.2 \mathrm{~m}$ from the traveled way to the barrier whenever practical. For further information, see the sections on "Shoulders" and Longitudinal Barriers"(Washington, D.C.: Transportation Research Board, 1999). Structures . The design of bridges, culverts, walls, tunnels, and other structures should be in accordance with the current Standard Specifications for Highway Bridges. The dimensional design of structures should also be in accordance with Reference (Washington, D.C.: Transportation Research Board, July 1999).Horizontal Clearance to Obstructions To the extent practical, where another highway or railroad passes over, the structure should be designed so that the pier or abutment supports have lateral clearance as great as the clear roadside area on the approach roadway.

\subsection{Design speed}

Design speed is generally used as the basic parameter in the specification of design standards, determining the minimum design value for other elements. The NSW Roads and Traffic Authority bases its current design standards on a travel speed rather than a design speed. Travel speed identifies a speed/horizontal radius relationship. This approach is intended for roads of a minimum travel speed of $60 \mathrm{~km} / \mathrm{h}$. The maximum speed limit in NSW for builtup areas is $50 \mathrm{~km} / \mathrm{h}$ as default speed limit and this should be used in calculating design values which depend on speed, (e.g. collector and subarterial roads) however, in difficult topography, the design speed may be reduced. Vehicular speeds are also limited by road intersections as well as changes in horizontal and vertical alignment. Adoption of a low design speed discourages speeding, however, where vertical or horizontal curves of low design speed are located in otherwise high speed sections (tangents) the result is a potentially dangerous section of road. It should be recognized that in low standard roads, operating speeds will tend to be in excess of arbitrary speed standards. Attention should be given to ensuring that potentially hazardous features are visible to the driver and adopting traffic engineering measures which will help a driver avoid errors of judgment. Generally, the following design speeds should be adopted: Access Street $40 \mathrm{~km} / \mathrm{h}$, Local Street $40 \mathrm{~km} / \mathrm{h}$ Collector Street $50 \mathrm{~km} / \mathrm{h}$, Distributor Road 60/80 km/h 


\subsection{Longitudinal gradient}

A general minimum gradient of 0.5 per cent should be adopted. In very flat conditions it may be reduced to 0.3 per cent subject to specific Council approval. Where underground drainage with gully pits or other special works are used it is preferable to allow near level grades rather than reverting to the unsatisfactory device of introducing artificial undulations. Variable cross fall may be necessary to produce the required grade in the gutter.

\subsection{Vertical curves}

Vertical curves will be simple parabolas and should be used on all changes of grade exceeding 1 per cent. The desirable minimum design speed is $60 \mathrm{~km} / \mathrm{h}$. The length of the crest vertical curve for stopping sight distance should conform to RTA Road Design Guide. These standards are based on 1.5 second's reaction time which provides a reasonable safety margin for urban conditions, where drivers' reaction time is usually considered to be lower than in rural conditions. For adequate riding comfort, lengths of sag vertical curves should conform with the RTA Road Design Guide. As residential roads are usually lit at night, the criterion for designing sag vertical curves is a vertical acceleration of $0.05 \mathrm{~g}$ for desirable riding comfort, and $0.10 \mathrm{~g}$ for minimum riding comfort.

\subsection{Super Elevation}

The use of super elevation in association with horizontal curves is an essential aspect of geometric design of roads with design speeds in excess of $60 \mathrm{~km} / \mathrm{h}$. Local access roads, which are designed for speeds of $40 \mathrm{~km} / \mathrm{h}$ or less and with curves of $60 \mathrm{mradius}$ or less generally have the pavement crowned on a curve instead of super elevation. Design standards for such curves have little meaning as drivers usually cut the corners and rely on friction to hold them on a curved path. As the radius of the curve falls, friction becomes more important than super elevation. The maximum super elevation for urban roads of higher design speeds should be6 per cent. Any increase in the longitudinal grade leading to excessive cross fall at intersections should be considered with caution. While it is desirable to super elevate all curves, negative cross fall should be limited to 3 per cent.

\subsection{Road width}

The effect of road width on driver speed choice seems to depend on the amount of pavement the driver perceives as usable. This affected by the lane width, number of lanes, shoulder width, presence of parked cars on the road edge and presence of vertical elements on the roadside. Wide lanes and or multiple lanes increase the area of road available to drive on (Elliot et ., 2003). Sealing and or widening the shoulder creates more perceived space for drivers, while the presence of parked cars reduces the area available for continuous driving without maneuvering around obstacles (Martens et al., 1997).

\subsection{Finance}

Funding for road work, new construction or improvements to existing highways, dependent on the economic benefit derived and expenditure has to be justified in terms of the resulting value. When demand, and suitable finance is available, projects will normally be directed at improving operational safety and efficiency and higher geometric standards are appropriate. When the network is inadequate in term of traffic demand, and finance is not readily available, lower geometric standards may sometimes be adopted on selected sections of road, provided an adequate operational improvement can be obtained (High way geometric design manual New Zealand April 2003)

\subsection{Temperature}

According to (Tom V Mathew and K V Krishna RAO 2007). The effect of temperature on asphalt pavements is different from that of concrete pavements. Temperature affects the resilient modulus of asphalt layers, while it induces curling of concrete slab. In rigid pavements, due to difference in temperatures of top and bottom of slab, temperature stresses or frictional stresses are developed. While in flexible pavement, dynamic modulus of asphaltic concrete varies with temperature.Frost heave causes differential settlements and pavement roughness. Most detrimental effect of frost penetration occurs during the spring break up period when the ice melts and subgrade is a saturated condition

\subsection{Precipitation}

The precipitation from rain and snow affects the quantity of surface water in ltrating into the sub grade and the depth of ground water table. Poor drainage may bring lack of shear strength, pumping, loss of support, (Tom V Mathew and K V Krishna RAO 2007). 


\section{RESEARCH METHODOLOGY}

The research methodology will explain how the objective of this study can be achieved. This study was carried out based on the literature review and questionnaire survey with three phases. Phase one was detailed group discussion on desk concentrating on literature review and development of the research instrument. The second phase involved data collection through the questionnaire from the respondents that are involved in construction projects. At the last phase collected data results were analyzed up on which the conclusion and recommendation were made. All the three phases involved discussions with project advisor. The methodology of this study was started from selection of topic then to identification of problem statement, literature review, data collection, analysis of results, discussion of results and forwarding the final conclusion sand recommendations. Figure shows a flow chart of the research methodology in order to achieve the objective of the study.

\subsection{Research methodology}

This study will start with problem identification. For an in depth understanding we will collect data by using both primary and secondary source of data. The primary source of data for the study was obtained through distribution of questionnaires to professionals involved in the construction sector. In order to enrich the questionnaire for the research, a review of books and journals will be used to identify the various efforts that have been made in the past to evaluate and examine the. Simple statistical analysis involving tables, rankings and percentages will be used in analyzing the results from the questionnaire. Descriptive explanations should also employed in making the analysis more meaningful. Secondary source which are data already collected by others and available in published and unpublished materials will be analyzed and findings are carried out. Data's includes data's collected from questionnaires and interviews to be gathered from owners, local contractors and consultant and other road construction sectors are entitled for questionnaire survey.

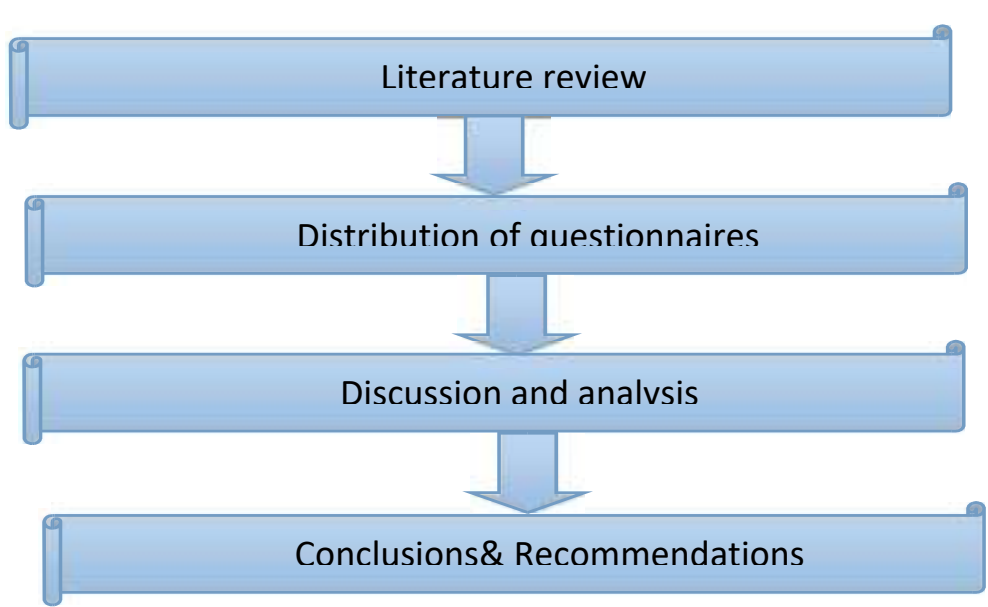

Figure 1:Research methodology

\subsection{Distribution of questionnaires}

The questionnaire was designed based on factors that affect road design, design consideration, design requirement for urban and rural road and how to minimize the design factors. A questionnaire survey was developed to assess the perception of contractor, and consultant of the relative importance of causes, effects and methods to minimize construction delay. The questionnaire was developed from literature review that was done through books, magazines and journals, the internet and other sources. 


\subsection{Source of data collected}

As we all know the source of data is an indispensable element in collecting\& logically analyzed data. When we say the source of data we are refereeing to the type of sources of from which the relevant data were collected. The researchers have used different methods for acquiring the data necessary for properly analyzing the research questions and reaching valid conclusion. Thus we can classify the source of data collected for the research in two major groups. Primary source is a data by which the researcher collets first hand. The first primary source of data for this research is data found by interviewing road engineers. This was mainly done to certain roads which would be more suitable for answering the research question. The researchers has utilized different secondary for this research. Among the secondary data the following are the main: Data found from south road authority regarding to the factors affecting road design in Wolaitasodo city is part of secondary data collected by the researchers. The other secondary data sources are data found from reference books and online resources.

\subsection{Methods of Data Collection}

Among the two most known and used data collection methods quantitative research is more logical and led approach which provides a measure of the research from astatically \& numerical point of view. Quantitative research can gather a large amount of that can be easily organized and that can be easily organized manipulated in to reports for analysis. It includes surveys, observation and reviews of records or documents for numeric information. The research has used this data collecting methods through looking at the records of roads design factors of the selected roads from the relevant offices. In addition to this the researchers has a collected \&analyzed the geometric design of the roads to understand what kind of factors were taken in designing the roads.

\subsection{Types of data collected}

The type of data collected are determined.

Observation: Observing randomly the geometry of roads as an engineer that could be cause factors in road design changes. Interviews: with road or site engineer to give in sight about when the design changes occur.

Documentary review: by analyzing the road geometric document of the relevant roads.

\subsection{Challenges Encountered In Data Collection}

Unavailability of data: during the period of data collection we are primary challenges are to find the relevant data from concerned bodies. Unfortunately some important data were not be found when looked for.

Available data were not clear and precise: this is also one of the challenges face by the researchers. Some of road design data taken from road authority are difficult to read. The relevant personnel: were too busy to assist our research question to get the necessary data because.

\section{DATA ANALYSIS}

\section{5 .1 RESEARCH DATA ANALYSIS METHODOLOGY}

This questionnaire was developed in order to know and judge the view of different construction professionals involved in the construction project in wolaitasodo city. We divided the questionnaire in to the following parts

Part 1 Information and background of the respondents

Part 2 factors affecting road design

Part 3 design criteria and its effectiveness for rural road (ways to minimize those factors)

Part 4 design criteria and its effectiveness for urban road (ways to minimize those factors)

\subsection{Data Analysis}

Before we started our analysis we checked the data that were collected and we arrange all the documents that collected and after finishing the arrangement of the data we started to prepare our analysis that was mentioned on the questionnaire. We adopted the weighted average (WA) statistical data analysis and (RII) method from the concept of our previous statistic knowledge. To make the results of this research more reliable we take the RII values up to three decimal rounds. Based on the RII value a rank was given to each factors, ways to minimize of their impact. But in the ranking portion there is an important point that you have to give a great attention.. And if they get the same rank then the next ranks following them will be ignored. Say for example three factors have an identical value of $\mathrm{RII}=0.624$ equivalent to the rank of six (6). Then the next larger value of RII= 0.612 have a rank of nine (9) but not 7 or 8. 


\subsection{Data Analysis for Most Common Impact Affecting Road Design}

We adopted a five-point scale ranging from 1 (very low impact) to 5 (Very high impact) and then for each causes we transformed the ranged values into WA and RII. The formulas mentioned above are described as follows.

$\mathrm{WA}=\sum\left(\mathrm{D}_{\underline{i}} \mathrm{~N}_{\mathrm{i}}\right) \Rightarrow \mathrm{WA}=\underline{1 \mathrm{n}^{1}+2 \mathrm{n}_{2}} \underline{\underline{\mathrm{N}}}+3 \mathrm{n}_{\underline{3}}+4 \mathrm{n}_{4}+5 \mathrm{n}_{5}$

$$
\mathrm{N}
$$

WA.....weighted average

$\mathrm{N}_{\mathrm{i}}$...number of respondents for that particular $\mathrm{i}^{\text {th }}$ degree

$\sum$....summation sign

$\mathrm{D}_{\mathrm{i}} \ldots \mathrm{i}^{\text {th }}$ degree of impact

$\mathrm{n}_{1} \ldots \ldots$ number of respondents for 1 degree of impact

$\mathrm{n}_{2} \ldots \ldots$ number of respondents for 2 degree of impact

$\mathrm{n}_{3} \ldots \ldots$ number of respondents for 3 degree of impact

$\mathrm{n}_{4} \ldots \ldots$ number of respondents for 4 degree of impact

$\mathrm{n}_{5} \ldots \ldots$ number of respondents for 5 degree of impact Type equation here.

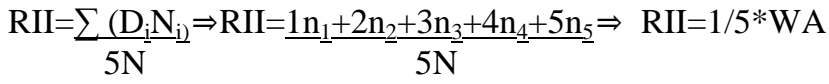

RII...relative importance index

$\sum$....summation sign

$\mathrm{D}_{\mathrm{i}} \ldots . . \mathrm{i}^{\text {th }}$ degree of impact

$\mathrm{N}_{\mathrm{i}}$...number of respondents for that particular $\mathrm{i}^{\text {th }}$ degree

N.....total number of respondents for the questionnaire

5 ...the higher degree of impact

$\mathrm{n}_{1} \ldots \ldots$ number of respondents for 1 degree of impact

$\mathrm{n}_{2} \ldots \ldots$ number of respondents for 2 degree of impact $\mathrm{n}_{3} \ldots \ldots$

number of respondents for 3 degree of impact

$\mathrm{n}_{4} \ldots \ldots$ number of respondents for 4 degree of impact $\mathrm{n}_{5} \ldots \ldots$

number of respondents for 5 degree of impact

N.....total number of respondents for the questionnaire

\subsection{ANALLYSIS FOR WAYS TO MININIMIZE THOSE IMPACTS (DESIGN CRITERIA)}

We adopted a five-point scale ranging from 1 (very less effective) to 5 (very highly effective) and then for each impact we transformed the ranged values into WA and RII. The formulas mentioned above are described as follows.

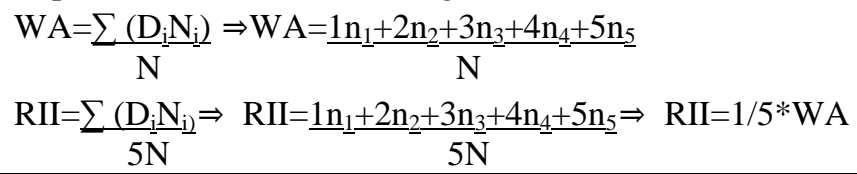

\begin{tabular}{|l|l|}
\hline symbol & Effects degree \\
\hline 1 & Very low influence \\
\hline 2 & Low influence \\
\hline 3 & Moderate influence \\
\hline 4 & High influence \\
\hline 5 & Very high influence \\
\hline
\end{tabular}

Table 1: factors affecting road design 


\begin{tabular}{|c|c|c|c|c|c|c|c|c|c|}
\hline \multirow{2}{*}{ № } & \multirow{2}{*}{ Major factors } & \multicolumn{5}{|c|}{ Degree of impact } & \multirow[b]{2}{*}{ WA } & \multirow[b]{2}{*}{ RII } & \multirow[b]{2}{*}{ RANK } \\
\hline & & $\begin{array}{l}1 \\
0\end{array}$ & 2 & 3 & 4 & 5 & & & \\
\hline 1. & $\begin{array}{l}\text { Foot paths: provision of a kerb provides visual and } \\
\text { some physical separation and assists in channeling } \\
\text { both the motorist and pedestrians }\end{array}$ & & 0 & 1 & 6 & 3 & 4.2 & 0.84 & 2 \\
\hline 2. & $\begin{array}{l}\text { Road alignment: provide adequate interaction } \\
\text { between motorist and pedestrian }\end{array}$ & 1 & 0 & 3 & 2 & 4 & 3.8 & 0.76 & 5 \\
\hline 3. & $\begin{array}{l}\text { Town planning: locating pedestrians and vehicles } \\
\text { roads within the town }\end{array}$ & 0 & 0 & 3 & 5 & 2 & 3.9 & 0.78 & 4 \\
\hline 4. & $\begin{array}{l}\text { Traffic and loading: contact pressure, wheel load, } \\
\text { axle configuration, moving loads, load, and load } \\
\text { repetitions }\end{array}$ & 0 & 0 & 1 & 2 & 6 & 4.1 & 0.83 & 3 \\
\hline 5. & $\begin{array}{l}\text { Road surface: Rough road surface leads to greater } \\
\text { noise and vibration inside the vehicle }\end{array}$ & 0 & 1 & 3 & 3 & 4 & 3.3 & 0.66 & 6 \\
\hline 6. & $\begin{array}{l}\text { Road width: lane width, number of lanes, shoulder } \\
\text { width, presence of parked cars on the road edge } \\
\text { and presence of vertical elements on the roadside. }\end{array}$ & 0 & 0 & 2 & 4 & 4 & 4.2 & 0.84 & 2 \\
\hline
\end{tabular}

Table 2: Geometrical factors

\begin{tabular}{|c|c|c|c|c|c|c|c|c|c|}
\hline \multirow{2}{*}{ № } & \multirow{2}{*}{ Major factors } & \multicolumn{5}{|c|}{ Degree of impact } & \multirow[b]{2}{*}{ WA } & \multirow[b]{2}{*}{ RII } & \multirow[b]{2}{*}{ RANK } \\
\hline & & $\begin{array}{l}1 \\
1\end{array}$ & 2 & 3 & 4 & 5 & & & \\
\hline 1. & $\begin{array}{l}\text { Temperature: affects the resilient modulus of } \\
\text { asphalt layers, while it induces curling of concrete } \\
\text { slab }\end{array}$ & & 1 & 2 & 0 & 7 & 4.5 & 0.9 & 1 \\
\hline 2. & $\begin{array}{l}\text { Precipitation: rain and snow affects the quantity of } \\
\text { surface water in ltrating into the sub grade and the } \\
\text { depth of ground water table }\end{array}$ & 0 & 1 & 1 & 4 & 4 & 3.1 & 0.62 & 8 \\
\hline 3. & $\begin{array}{l}\text { Finance: the influence of the new output road of } \\
\text { road }\end{array}$ & 0 & 1 & 1 & 4 & 4 & 3.1 & 0.62 & 8 \\
\hline 4. & $\begin{array}{l}\text { Terrain: is a significant on the costs of achieving } \\
\text { ahigh standard road alignment }\end{array}$ & 0 & 0 & 6 & 0 & 4 & 3.8 & 0.76 & 5 \\
\hline 5. & $\begin{array}{l}\text { Safety: items such as traversable batter slopes, } \\
\text { guard rails, breakaway light columns and sign } \\
\text { supports are desirable features of what has been } \\
\text { described as a forgiving roadside }\end{array}$ & 0 & 0 & 5 & 3 & 2 & 3.7 & 0.74 & 6 \\
\hline
\end{tabular}

Table 3: Environmental factors 


\section{RESULT DISCUSSION}

\subsection{The most impact on road design}

In the analysis part we have seen that most impact that affect road design those impacts were ranked based on the relative importance index value. The values of the relative importance index of major impact that affect road design that are initiated by construction professionals were compared all together and the rank was given in that sense.as we seen on the above table

\begin{tabular}{|l|l|l|l|}
\hline No & The most impact on road design & RII & Rank \\
\hline 1 & $\begin{array}{l}\text { Temperature: affects the resilient modulus of asphalt layers, while it induces } \\
\text { curling of concrete slab }\end{array}$ & 0.9 & 1 \\
\hline 2 & $\begin{array}{l}\text { Road width: lane width, number of lanes, shoulder width, presence of parked cars } \\
\text { on the road edge and presence of vertical elements on the roadside. }\end{array}$ & 0.84 & 2 \\
\hline 3 & $\begin{array}{l}\text { Foot paths: provision of a kerb provides visual and some physical separation and } \\
\text { assists in channeling both the motorist and pedestrians }\end{array}$ & 0.84 & 2 \\
\hline 4 & $\begin{array}{l}\text { Traffic and loading: contact pressure, wheel load, axle configuration, moving } \\
\text { loads, load, and load repetitions }\end{array}$ & 0.83 & 3 \\
\hline 5 & Town planning: locating pedestrians and vehicles roads within the town & 0.78 & 4 \\
\hline 6 & $\begin{array}{l}\text { Road alignment: provide adequate interaction between motorist and pedestrian } \\
\text { Terrain: is a significant on the costs of achieving a high standard road alignment }\end{array}$ & 0.76 & 5 \\
\hline 7 & $\begin{array}{l}\text { Tafety: items such as traversable batter slopes, guard rails, breakaway light } \\
\text { columns and sign supports are desirable features of what has been described as a } \\
\text { forgiving roadside }\end{array}$ & 0.74 & 6 \\
\hline 9 & $\begin{array}{l}\text { Road surface: Rough road surface leads to greater noise and vibration inside the } \\
\text { vehicle }\end{array}$ & 0.66 & 7 \\
\hline 10 & $\begin{array}{l}\text { Precipitation: rain and snow affects the quantity of surface water in trading into } \\
\text { the sub grade and the depth of ground water table }\end{array}$ & 0.66 & 7 \\
\hline 11 & Finance: the influence of the new output road of road & 0.62 & 8 \\
\hline
\end{tabular}

\section{Table 4:The most impact on road design}

As clearly observed in the above table the construction professionals tried to address the following information's , temperature is the most common impact and it ranked firstly out of 11 impacts as described above. These 11 impacts were derived from the literature review of our research conducted. And as we seen the preceding most impact is road width and foot path respectively and temperature is the most common impact that affect road design. From the 11 lists of impacts that affect road design perception and finance are the least impact which affect road design in which perception RII is 0.66 and finance is RII is 0.62 . To conclude the most common impacts are temperature and road width as the construction professional described under the questionnaire and finance and perception are the leas impacts that affect road design Part III Design criteria and its effectiveness 


\begin{tabular}{|c|c|c|c|c|c|c|c|c|c|}
\hline \multirow[b]{2}{*}{ No } & \multirow[b]{2}{*}{ Ways to minimize factors For urban road } & \multicolumn{5}{|c|}{ Degree of effectiveness } & \multirow[b]{2}{*}{ WA } & \multirow{2}{*}{ RII } & \multirow[b]{2}{*}{ RANK } \\
\hline & & 1 & 2 & 3 & 4 & 5 & & & \\
\hline 1. & $\begin{array}{l}\text { Road hierarchy: A hierarchical road network is } \\
\text { essential to maximize road safety, residential } \\
\text { amenity }\end{array}$ & 0 & 1 & 4 & 2 & 3 & 3.8 & 0.76 & 5 \\
\hline 2. & $\begin{array}{l}\text { Design speed: Design speed is generally used as } \\
\text { the basic parameter in the specification of design } \\
\text { standards, determining the minimum design value } \\
\text { for other elements }\end{array}$ & 1 & 0 & 0 & 7 & 2 & 3.8 & 0.76 & 5 \\
\hline 3. & $\begin{array}{l}\text { Longitudinal gradient: A general minimum } \\
\text { gradient of } 0.5 \text { per cent should be adopted. }\end{array}$ & 0 & 0 & 5 & 3 & 2 & 3.7 & 0.74 & 6 \\
\hline 4. & $\begin{array}{l}\text { Vertical curves:Vertical curves will be simple } \\
\text { parabolas and should be used on all changes of } \\
\text { grade exceeding } 1 \text { per cent. }\end{array}$ & 0 & 0 & 6 & 0 & 4 & 3.8 & 0.76 & 5 \\
\hline 5 & $\begin{array}{l}\text { Super Elevation for urban:The use of super } \\
\text { elevation in association with horizontal curves is } \\
\text { an essential aspect of geometric design of roads } \\
\text { with design speeds in excess of } 60 \mathrm{~km} / \mathrm{h}\end{array}$ & 0 & 0 & 3 & 4 & 3 & 4.0 & 0.8 & 3 \\
\hline
\end{tabular}

Table 5: Design requirements for urban road

\begin{tabular}{|c|c|c|c|c|c|c|c|c|c|}
\hline \multirow[b]{2}{*}{ No } & \multirow[b]{2}{*}{ Design requirements } & \multicolumn{5}{|c|}{ Degree of effectiveness } & \multirow{2}{*}{ WA } & \multirow{2}{*}{ RII } & \multirow{2}{*}{ RANK } \\
\hline & & 1 & 2 & 3 & 4 & 5 & & & \\
\hline 1. & $\begin{array}{l}\text { Sight distance: should be provided at all points on } \\
\text { the road }\end{array}$ & 0 & 0 & 3 & 6 & 1 & 4.3 & 0.86 & 1 \\
\hline 2. & $\begin{array}{l}\text { Horizontal and vertical alignment: should be } \\
\text { designed to conform with the terrain to achieve } \\
\text { desirable aesthetic Quality and being in harmony } \\
\text { with the landform. }\end{array}$ & 0 & 0 & 5 & 3 & 2 & 3.7 & 0.74 & 6 \\
\hline 3. & $\begin{array}{l}\text { Plan transitions: proposed roads are curved, the } \\
\text { adequacy of carriage away width should be }\end{array}$ & 0 & 0 & 3 & 5 & 2 & 3.9 & 0.78 & 4 \\
\hline 4. & $\begin{array}{l}\text { Super elevation for rural:Use of maximum super } \\
\text { elevation will be considered where the radius of } \\
\text { the curve in approaching the minimum speed } \\
\text { environment. }\end{array}$ & 0 & 0 & 4 & 2 & 2 & 3.0 & 0.6 & 7 \\
\hline 5. & $\begin{array}{l}\text { Scour protection:The level of protection will } \\
\text { depend on the nature of the soils, road gradients } \\
\text { and volume of storm water runoff. }\end{array}$ & 0 & 0 & 2 & 4 & 4 & 4.2 & 0.84 & 2 \\
\hline
\end{tabular}

Table 6: Design requirement for rural road 


\subsection{Ways to Minimize Those Factors On Road Design}

As we seen in the analysis part we tried to mention that those the design requirements which are ways to minimize those factors affecting road design are ranked according to the relative importance index value.so under this discussion we tried to arrange those ways to minimize based on the ranks they get

\begin{tabular}{|l|l|l|l|}
\hline No & Ways to minimize those impacts & RII & RANK \\
\hline 1 & Sight distance: should be provided at all points on the road & 0.86 & 1 \\
\hline 3 & $\begin{array}{l}\text { Scour protection: The level of protection will depend on the nature of the } \\
\text { soils, road gradients and volume of storm water runoff. }\end{array}$ & 0.84 & 2 \\
\hline 4 & $\begin{array}{l}\text { Super Elevation for urban: The use of super elevation in association with } \\
\text { horizontal curves is an essential aspect of geometric design of roads with } \\
\text { design speeds in excess of } 60 \text { km/h }\end{array}$ & 0.8 & 3 \\
\hline 5 & $\begin{array}{l}\text { Plan transitions: proposed roads are curved, the adequacy of carriage away } \\
\text { width should be }\end{array}$ & 0.78 & 4 \\
\hline 6 & $\begin{array}{l}\text { Road hierarchy: A hierarchical road network is essential to maximize road } \\
\text { safety, residential amenity }\end{array}$ & 0.76 & 5 \\
\hline 7 & $\begin{array}{l}\text { Vertical curves: Vertical curves will be simple parabolas and should be used } \\
\text { on all changes of grade exceeding 1 per cent }\end{array}$ & $\begin{array}{l}\text { Design speed: Design speed is generally used as the basic parameter in the } \\
\text { specification of design standards, determining the minimum design value for } \\
\text { other elements }\end{array}$ & 0.76 \\
\hline 8 & $\begin{array}{l}\text { Horizontal and vertical alignment: should be designed to conform with the } \\
\text { terrain to achieve desirable aesthetic Quality and being in harmony with the } \\
\text { landform. }\end{array}$ & 5.74 & 5 \\
\hline
\end{tabular}

As you see above the first possible way to minimize with RII=0.86 is site distance. And scour protection are the second and third impacts of delay with RII value 0.84 and 0.8 respectively. The lastly ranked ways to minimize, was given the least degree of effectiveness by the respondents relatively to other impacts of delay and as you see above it has got RII value of 0.74

\section{CONCLUSION}

Several factors affecting pavement design were discussed, the most important being wheel load. Since pavements are designed to take moving loads, slow moving loads and static loads can be detrimental to the pavement. Temperature also influences pavement design especially the frost action which is very important in cold countries. This chapter presents the findings that are to be concluded from the Literature Review and questionnaire survey with some forwarded recommendations to the Employer for its implementation of the road construction projects in Ethiopia . There are three objectives of this study which have been achieved. The first to identify the major factors that affect road design ,how to minimize these factors and which factors have the most impact road design the major factors road design, how to minimize these factors and the method of minimizing these factors is clearly detailed. Design factors can be minimized and known. The aim of this research is to identify these factors, how to minimize these factors and identify the most impact on road design.

Problems and disputes are a means for road design time overruns. So a need to procure a qualified design consultant (i.e. recruiting and assigning of qualified clients representatives), reviewing of the qualified personnel's and introducing of quality assurance systems is due required to minimize road construction time overruns. Timely removal of obstructions and late issue of site hand over are also the main causes of road construction delays resulting from the poor communication between the Federal and Local Road Authorities and poor organization of right of way departments and responsibilities. Therefore, a need to communicate with the local authorities and strengthen the right of way departments is important. One of the big problems observed for while managing and administering construction projects is proper record keeping which is one of the basic requirements for solving construction claims 
and disputes, so a need to have proper recording and keeping is due important. Selection of best performing contractors and consultants through performance evaluation system and awarding bids to the right/experienced consultant and contractor is also an important way of minimizing road construction delays. A need to install a fast decision making procedures for problems during the construction contract implementation process are among the effective method in reducing road construction time overruns.

\section{REFERENCE}

[1] Transportation Research Board Executive Committee, "NDT Technology for quality assurance of HMA pavement construction," NCHRP Report No. 626, 2009, Washington, D.C., USA.

[2] J. A. Deacon, C. Monismith, J. Harvey, and L. Popescu, "Pay factors for asphalt-concrete construction: effect of construction quality on agency costs," Technical Memorandum, TM-UCB-PRC-2001-1, Pavement Research Center, Institute of Transportation Studies, 2001, University of California, Berkeley, California, USA.

[3] S.P. La Hue, "Quality assurance and quality of construction," Quality Assurance in Pavement Construction, Ed. Allen, G. J., ASTM STP 709, Philadelphia,1980, USA, 3-10.

[4] BIAM "Construction quality," 57 BIAM Supplement No.2, Bureau of Indian Affairs Manual, 2008, Washington, D.C, USA.

[5] S. Pathomvanich, "Assessment of the effectiveness of quality assurance construction specifications for asphaltic concrete pavement," PhD Thesis, Department of Civil and Coastal Engineering, 2000, Graduated School, Florida University, USA.

[6] H.F. Thurner, "Quality assurance and self-control in road construction, advanced measurement technology." Technical Paper, Geodynamic AB, Stockholm, 2001, Sweden, No.11, 1-10.

[7] AASHTO. 1993. Guide for Design of Pavement Structures. American Association of State Highway and Transportation Officials. Washington D.C.

[8] American Standard Test Method (ASTM) C39/C39M-01. 2001. Standard Test Method for Compressive Strength ofCylindrical Concrete Specimens. West Conshohocken, PA.

[9]American Standard Test Method (ASTM) C133-97. 1997. Standard Test Methods for Cold Crushing Strength and Modulus ofRupture ofRefractories. West Conshohocken, P A.

[10] American Standard Test Method (ASTM) C426-99. 1999. Standard Test Methodfor Linear Drying Shrinkage ofConcrete Masonry Units. West Conshohocken, PA. 